\title{
Training Seafarers for Tomorrow: The Need for a Paradigm Shift in Admission Policies
}

\author{
Livingstone Caesar*, Stephen Cahoon \\ Australian Maritime College, University of Tasmania, Australia
}

Copyright (C) 2015 Horizon Research Publishing All rights reserved.

\begin{abstract}
The traditional approach used by MET institutes to admit students who are trained to become seafarers is increasingly becoming deficient in the face of the growing labour crisis within the global shipping industry. Further pressure is being placed on MET institutes to revise the modus operandi used to enroll students due to the dynamic nature of the seafaring labour landscape. Due to the limited knowledge MET institutes have about the students they admit, their expectations and career ambitions, it is difficult to effectively retain them onboard ships. This is because the lack of information on the career ambition of the students translates into poor management of their expectations. This paper discusses the need for MET institutes to employ psychological testing tools to gather adequate information about the students at the time of admission. This is necessary as it will help both the trainers of seafarers and shipping industry employers to adequately manage their expectations. When the expectations of students are not known, it consequently leads to a poor management of their career ambitions which then culminates in attrition from ships to landside jobs when they become seafarers. Thus MET institutes need to know the kind of people they are recruiting in order to effectively manage their expectations and this requires a thorough understanding of the reasons and factors influencing people to enter into seafaring.
\end{abstract}

Keywords Ship Officers, Seafaring, Shipping, Admission Policy, Shortage, Students, Recruitment and Retention

\section{Introduction}

The traditional approach used by maritime education and training (MET) institutes to admit seafaring students is increasingly under pressure due to the growing labour crisis within the global shipping industry $[1,2]$. Further stress is evident for MET institutes to revise their modus operandi for enrolling students given the dynamic nature of the seafaring labour landscape. The limited knowledge MET institutes have about the students they admit, in particular their expectations and career ambitions, may be resulting in the reduced retention of the new cadets onboard ships. This lack of information of the student's career aspirations may translate into poor management of their expectations [3].

After a careful scrutiny of the cadet admission forms of 20 universities who form part of the 57 member institutions of the International Association of Maritime Universities (IAMU), this paper discusses the need for MET institutes to employ psychological testing tools to gather adequate information about the students at the time of admission. This is necessary as it will help both the trainers of seafarers and shipping industry employers to adequately manage their expectations. When the expectations of students are not understood, it may consequently lead to the poor management of their career aspirations which may result in attrition from ships to landside jobs when they become seafarers. Thus MET institutes should make efforts to better understand who they are recruiting in order to effectively manage their expectations. This requires a thorough understanding of the factors influencing people to opt for a seafaring career.

\section{The Shortage of Ship Officers}

Available research relating to seafarers suggests a future shortage of ship officers. Specifically, the statistics suggests a global deficit of 13,000 - 30,000 ship officers [4-6]. In relation to the shortage of ship officers, Leong [7] identifies a web of issues connected to changes in the sources of the supply of seafarers. This, in addition to a complex range of retention issues is influencing the global shortage of ship officers. Thomas, Sampson [8] note there is a growing concern among the international maritime community about the overall need for additional qualified ship officers in the $21^{\text {st }}$ century. The shortage of ship officers has many negative consequences for the shipping industry. With the growing size of maritime trade, there is an inevitable need for ships to convey seaborne cargo [9] from the origin to countries where they are in high demand. Since ship officers are needed for the safe navigation and operation of these vessels [10], a 
shortage will prove counterproductive to the growth of the maritime industry and disastrous from a safety perspective. Furthermore, the availability of ship officers is not only necessary for the operation of a growing world fleet, but also as an eventual employment source for related industries ashore [11-13]. Essentially, the demand for ship officers is a derived one which is highly influenced by demand for shipping services [6]. Therefore, it is an issue that should strongly feature on the agenda of shipping industry employers.

Thus, the global shortage of ship officers is receiving increasing attention as shipping industry employers consider how they will continue to safely operate their vessels. Practically, the movement of seafarers from vessels to landside jobs in ports and ship management establishments has been identified as a primary contributing factor to the global shortage of ship officers [3, 14-16]. Thus the need to focus on ship officer retention has been informed by the findings of the existing literature (such as recurring wastage and reduction in the number of years spent at sea by officers) that the shortage of ship officers is not necessarily influenced by low recruitment figures but rather by the early movement of ship officers to shore based jobs.

Shiptalk [17] found in a survey of 229 seafarers that approximately one third intended to make seafaring a lifelong career, while two thirds indicated they would move ashore as soon as circumstances permitted due mainly to there being few career prospects and the length of time spent away from family. Ljung [18] noted that the number of years spent at sea by ship officers has reduced in recent times with seafarers now working seven years or sometimes less before departing for jobs onshore. Statistics from Denmark suggest that many ship officers are retiring from sea at the early age of 40 to take up landside maritime jobs [6]. The early retirement of ship officers creates critical vacancies at the helms of ships which industry employers may not be able to fill immediately as it takes an average of ten years to prepare cadets to become ship officers $[4,19]$. Similarly, Fastream [20] identified that most ship officers leave to landside jobs within ten years; with some becoming high earners due to the rapid career progression they enjoy onshore. In the United Kingdom for instance, Gardner and Pettit [11] found that people with seafaring skills and experience are preferred for 70 per cent of landside maritime jobs with 87.5 per cent of the positions going to ex-ship officers. According to Barnett, Gatfield [21], this high preference for ex-seafarers is due to their substantial knowledge of ships and maritime procedures as well as leadership potential. If seafarer retention onboard is not improved, seafaring as a lifetime career will eventually disappear. This becomes more likely when combined with structural changes in the industry such as advanced handling technology that reduces time in port, in some cases only 24-36 hours, thus providing little time for the much sought after shore leave $[22,23]$ even if in ports in remote locations away from city centres.

\section{Existing Strategies}

As a result of the global shortage of ship officers and the dynamic nature of the seafarer labour markets, shipping industry employers need to adopt appropriate measures to improve the future supply of maritime labour. As per the challenges posed by the prevailing seafarer recruitment methods, efforts must be made at the organisation and industry level to address issues that hinder effective recruitment as inadequacies at both of these levels have equally contributed to the current shortage of ship officers [24-26]. Effective recruitment of seafarers should entail a crewing strategy that is aimed at ensuring a constant flow of seafarers to meet the needs of industry employers. There is a need for strategies capable of attracting recruits to a seafaring career. To make an organisation successful in building a brand towards the attraction of prospective employees, Wilden, Gudergan [27] suggest the need for an effective recruitment strategy. The call for corporate social responsibility (CSR), for example, among shipping industry employers is a necessary recruitment strategy that can position them as attractive brands to job seekers who may become potential employees [28-30]. Internal marketing is another strategy that could also boost the recruitment of seafarers [31, 32].

Research has already suggested that a poor industry image is one of the issues negatively affecting the attraction of people into seafaring [31, 33, 34]. Cahoon and Haugstetter [14] suggest that the increasing rate of exit of seafarers may also be due to this negative image while Magramo and Gellada [35] found this to be more prevalent among the younger generation. This will only add to the shortage of ship officers as their skills become sought after onshore [32, 36, 37]. To address the identified global shortage of ship officers [4], improving the image of shipping industry organisations needs to be considered a necessity $[14,31,38$, 39]. Considering that seafaring is not actively promoted as a professional career $[16,40]$, coupled with a need to increase the supply of seafarers, the adoption of industry and employer branding strategies is recommended among other things to transform the shipping industry into an industry of choice (IOC) [14, 31, 41].

The aim of an IOC strategy for the shipping industry should be to differentiate the seafaring career from other industries (such as mining) that are equally competing for skilled talent [32]. Thus image branding for the shipping industry is necessary towards improving the recruitment of seafarers. This involves a proactive coalescence of employer of choice (EOC) and IOC strategies [32] which uses both marketing and corporate social responsibility principles as a means of building strong employer brands towards the attraction of people into seafaring [42]. The adoption of an IOC strategy to improve recruitment of seafarers is necessary as it is argued [see for example, 38, 43] that the global shortage of ship officers should be addressed with relevant strategies from the industry perspective since the effort of one or a few organisations is not likely to make any 
meaningful impact on recruitment.

The hiring practices of shipping industry employers should be targeted at meeting the career expectations of recruits. It must be realistic and form part of the strategies used during the recruitment stage so that recruits have a realistic preview of working onboard ships. The literature suggests that EOC and IOC strategies can be effective in the management of expectations [see for example, 31, 38, 39, 41, 44]. It will however take the concerted effort of stakeholders at all levels of the shipping industry to achieve improved onboard working and living conditions for seafarers. In the case of maritime unions who constitute part of the spectrum of industry stakeholders [45], forming a united front to push forward an agenda for respect of the rights of seafarers under the Maritime Labour Convention (MLC) is part of the overall improvement needed [46, 47].

To improve the recruitment of entrants, especially young people into the seafaring profession; there are other options open to both industry employers and MET institutes. Most traditional maritime countries within the Scandinavian region and Eastern Europe rely on campaign programmes which are similar in modus operandi across the geographical spread, to attract young people into seafaring [48]. The internet and electronic media act as very important tools in the process. Due to the challenge that comes with combining seafaring occupation and a healthy family life [8, 49], Zaar and Hammarstedt [48] found that most young people from traditional maritime nations will not want to take up seafaring as a career and even if they do, recommending it to others becomes difficult. Campaigns and promotions aimed at recruitment of seafarers must be designed to educate young people about the benefits of careers in shipping in order to boost the number of people attracted to work at sea.

Barnett, Gatfield [21] concluded that although many industry players acknowledge the increasing shortage of ship officers there appears to be an absence of a definite plan on how the problem will be addressed. Several propositions are evident in the literature as the means to address the problem of high mobility among ship officers and improve retention of seafarers in general. The most common include: improving welfare and working conditions, funding of training and skills development, and mapping out a long-term career plan for seafarers [50-54]. According to Nigel [26], the provision of attractive remuneration and adequate motivation are also used by some ship management companies in a bid to improve retention among crew [55]. Studies have however confirmed that organisations cannot rely on monetary rewards alone to achieve the desired level of retention among staff because it is a more complex and multi-faceted issue and one where the solution becomes the poaching of seafarers by offering higher and higher salaries.

To address the ship officer shortage problem in the shipping industry, Fei [56] proposed the maintenance of a rich knowledge base through proactive knowledge management practices. The author then concluded that conventional human resource management practices are not enough to address the labour challenges faced by the shipping industry. Such a conclusion however, provokes a number of questions because the problem being experienced by the shipping industry is recruitment and retention $[4,14$, $25,39,57]$ and it is a global concern [4]. Studies have confirmed that the area of retention needs more attention in order to manage the expectations and realities of people who come into the shipping industry $[14,31,41]$ - these are issues that are purely human resource management based. It therefore means that, application of human resource theories can be viewed as the plausible approach. Also, human resource practices in seafaring have been recognised as being poor [30, 43, 58, 59]; and this needs adequate attention and refocusing in order to develop a more effective scheme that makes a meaningful impact on both the recruitment and retention of seafarers.

There are serious questions that can be raised with regards to the retention of knowledge instead of labour itself. For instance, how can the retention of knowledge in a bulk shipping company help in solving the shortage of officers in the specialized tanker trades sector (chemical, LNG and LPG)? With regards to the shortage of officers for LNG carriers for instance, Yamamoto [60] found that there is shortage in capacity for educating and training as well as lack of opportunities to exchange accumulated knowledge and expertise in that area. Also, the proposed retention of knowledge is at the organisational level whereas the shortage of ship officers is an industry-wide problem which $[13,18,20,61]$ is compounded by the progressive reduction in the number of active years spent at sea by officers. Also, the high occupational mobility among ship officers is happening at both national and international levels [6]; hence the need for a solution from a multilevel perspective. This paper proposes that understanding the career ambitions of seafaring students admitted into MET institutes through appropriate psychological testing is part of the multilevel approach needed to improve the retention and eventually stabilise the global supply of ship officers. The psychological tests should be for new recruits and needs to determine their ability to withstand stress before admitting them onboard ships; as stress is acknowledged as a daily phenomenon in the working life of seafarers.

\section{Methodology}

The primary purpose of this paper is to answer the following questions: (1) What is the nature of information collected by MET institutes from prospective seafaring students at the time of admission? (2) How relevant is the collected information in forecasting the career ambitions of the students? (3) What sort of information should MET institutes collect from students to properly forecast their career ambitions? Document analysis was used as the main data collection and analysis method $[62,63]$ to investigate the three questions. This is a qualitative research technique 
which essentially involves the interpretation of institutional or policy documents by the researcher. In total, 20 admission forms of universities who form part of the 57 member institutions of the International Association of Maritime Universities (IAMU) were analysed. The four issues discussed by Scott [64] as being critical for the document analysis method: authenticity, credibility, representativeness and meaning, were observed in the handling of the admission forms used in this study. The primary aim of the document analysis methods is to improve understanding of the phenomenon being studied [65]. In the document analysis method, the contents of the document were coded into themes.

A purposive sampling technique was used to select the sample size of 20 MET institutes from the population lists of 57 from the 2013-2014 Times Higher Education World University Rankings [66] based on the prior industry knowledge and experience of the researchers. Care was taken to use only the 57 IAMU members as the population list for the current study. This approach was necessary to help avoid the inclusion of other MET institutes that may be considered to be of a lower quality. Additionally, the IAMU has a culture which involves a stringent application of quality standards for members with regards to training requirements as per the International Convention on Standards of Training, Certification and Watchkeeping (STCW). Furthermore, 20 admission forms were sampled (5 of the forms were web-based - that is needs to be completed online) because a point of saturation for data may be reached after the twentieth admission form [67].

\section{Results and Implications}

Table 1 shows a summary of the most common information collected from potential seafaring students as shown on the enrolment forms from the 20 MET institutes. Through the analysis, four key groupings of data collected by the selected universities from potential seafaring students were identified: (1) course details, (2) demographic data, (3) contact information and (4) health related information.

Table 1. Summary of data collected from potential seafaring students.

\begin{tabular}{|c|c|c|c|c|}
\hline Admission form No. & Course details & Demographic data & Contact information & Health related \\
\hline 1 & $\checkmark$ & $\checkmark$ & $\checkmark$ & $\checkmark$ \\
\hline 2 & $\checkmark$ & $\checkmark$ & $\checkmark$ & $\checkmark$ \\
\hline 3 & $\checkmark$ & $\checkmark$ & $\checkmark$ & $\checkmark$ \\
\hline 4 & $\checkmark$ & $\checkmark$ & $\checkmark$ & $\checkmark$ \\
\hline 5 & - & $\checkmark$ & $\checkmark$ & $\checkmark$ \\
\hline 6 & $\checkmark$ & $\checkmark$ & $\checkmark$ & $\checkmark$ \\
\hline 7 & $\checkmark$ & $\checkmark$ & $\checkmark$ & $\checkmark$ \\
\hline 8 & - & $\checkmark$ & $\checkmark$ & $\checkmark$ \\
\hline 9 & $\checkmark$ & $\checkmark$ & $\checkmark$ & $\checkmark$ \\
\hline 10 & - & $\checkmark$ & $\checkmark$ & $\checkmark$ \\
\hline 11 & $\checkmark$ & $\checkmark$ & $\checkmark$ & $\checkmark$ \\
\hline 12 & $\checkmark$ & $\checkmark$ & $\checkmark$ & $\checkmark$ \\
\hline 13 & - & $\checkmark$ & $\checkmark$ & $\checkmark$ \\
\hline 14 & $\checkmark$ & $\checkmark$ & $\checkmark$ & $\checkmark$ \\
\hline 15 & $\checkmark$ & $\checkmark$ & $\checkmark$ & $\checkmark$ \\
\hline 16 & $\checkmark$ & $\checkmark$ & $\checkmark$ & $\checkmark$ \\
\hline 17 & $\checkmark$ & $\checkmark$ & $\checkmark$ & $\checkmark$ \\
\hline 18 & - & $\checkmark$ & $\checkmark$ & $\checkmark$ \\
\hline 19 & $\checkmark$ & $\checkmark$ & $\checkmark$ & $\checkmark$ \\
\hline 20 & $\checkmark$ & $\checkmark$ & $\checkmark$ & $\checkmark$ \\
\hline
\end{tabular}


Course details: All but five of the admission forms $(\mathrm{n}=20)$ did not have a section where potentials students are asked to give details about the course they intend to pursue. The details of the relevant course are provided in the prospectus or promotion material of the MET institute for students to choose and complete on the form. The courses are either deck or engine based to reflect the two key departments of oceangoing ships. Six of the admission forms already included the courses for students to simply tick.

Demographic data: All 20 admission forms analysed requested demographic data from potential students including their full names, biographical data (education level, employment status, awards, etc.), gender, details of parents and siblings, and nationality.

Contact information: All 20 admission forms included sections for contact details such as the home address, emergency address, and phone and email contact details. Surprisingly, only four requested the student's email address which is unusual considering the high internet usage among Generation Y students and workers [68, 69].

Health related: All 20 admission forms required potential students to provide information on their health status. The required information was mostly related to knowing whether students had chronic sicknesses and medical conditions that may affect their ability to work at sea after the MET training. Students were also expected to declare their medical status in relation to sicknesses such as hypertension, diabetes, disability, etc.

Miscellaneous: The majority of admission forms did not have a miscellaneous section for students to provide further information on their application. However six had a section for students to provide information on scholarships, sponsorships, and hobbies. Only one admission form had details on student interview arrangements.

Clearly the most significant information collected by MET institutes from potential seafaring students tends to be biographical data. This primarily concerns personal details such as name, gender, date of birth, educational background and contact details. At best, the information collected from students could be used by the MET institutes to segment and compare the students' grades and results based on their demographics such as schools attended, earlier education grades and/or geographic location.

Unfortunately for the shipping industry, a major opportunity has been missed by the MET institutes to collect data from potential seafaring students that may forecast there actual career aspirations and potential to succeed and remain at sea. For example, the inclusion of questions asking why students chose the course and their ambitions may provide useful insights that could be used by MET institutes to assist with marketing efforts as well as providing reasons why students believe the shipping industry is an IOC. The request for some health information appears to be essentially the most potentially useful information collected, but whether this is passed on to recruiters is unknown.

\section{Recommendations and Suggestions}

This paper suggests that future admission forms used in the enrolment of seafaring students should be re-designed to solicit information that potentially makes it possible for the career aspirations of shipping graduates to be analysed. Specifically, the following questions on future admission forms can be relevant:

1. Why did you choose to study a shipping-related course in this institute?

2. In which jobs do you hope to be employed after graduation?

3. Briefly describe your future career ambitions, including where you hope to be employed in ten and twenty years' time.

4. What do you know about the working career of seafarers?

One of the key limitations of the current study is its sole reliance on document analysis as the method of data collection and analysis. It is recommended that future research following the same manner of technique used in this paper could be enriched by including key informant interviews of student registration officials from the admission office of the MET institutes. The interviews would complement the document analysis and provide further insights and explanations of what may be the most appropriate details to include and which questions may be too difficult for potential students to answer.

To obtain a better sense of how the background of students may influence their career decisions and future employment plans, it is also recommended that the methodology of future research should consider a web-based survey of students currently enrolled in the MET institutes. Potentially the 57 MET institutes that are members of the IAMU can collaborate on this area of research by working together to develop a standard survey instrument and thus eventually a standardised admission form. Also, the collaboration could mean a relatively easy access to a large population set of current students for the study. Although educational data mining is equally an effective means of mapping the background data on students against their probable career ambitions, it is a method that is more likely to be hindered by ethical and data protection policies.

\section{REFERENCES}

[1] Cahoon, S., D.L. Caesar, and J. Fei, Human resource practices in seafaring: Opportunities for improving retention, in Contemporary marine and maritime policy, J. Xu, Editor, Nova Science Publishers: New York. 85-103, 2014

[2] Donner, P. Reasons for and insurance implications of the manning crisis. in 2nd International Scientific Maritime Conference on Human Resources in the Shipping Industry: 
New Trends and Challenges in the 21st Century. Limassol, Cyprus., 2008

[3] Caesar, D.L., S. Cahoon, and J. Fei. Breaking the psychological contract and managing expectations: Developing solutions for the shortage of ship officers. in 2013 International Association of Maritime Economists Conference. Marseille, France, 2013

[4] BIMCO/ISF, BIMCO/ISF manpower update: The worldwide demand for and supply of seafarers, Dalian Maritime University and Institute for Employment Research, University of Warwick. 2010.

[5] Drewry, S.C., Manning manpower update, Drewry Publishing: London. 2009.

[6] McLaughlin, H.L., Seafarers and seafaring, in The Blackwell companion to maritime economics, W.K. Talley, Editor, Wiley-Blackwell: Oxford, UK. 321-332, 2012

[7] Leong, P., Understanding the seafarer global labour market in the context of a seafarer 'shortage', in School of Social Sciences2012, Cardiff University: Cardiff.

[8] Thomas, M., H. Sampson, and M. Zhao, Finding a balance: Companies, seafarers and family life. Maritime Policy \& Management, Vol.30 No.1, 59-76, 2003.

[9] Fernando, S., China's post-1978 maritime relations with South Asia: Towards greater cooperation. Strategic Analysis, Vol.36 No.3, 461-476, 2012.

[10] Branch, A.E., Elements of shipping. 8th ed, Routledge: United Kingdom. 2007.

[11] Gardner, B. and S. Pettit, The land-based jobs market for seafarers consequences of market imbalance and policy implications. Marine Policy, Vol.23 No.2, 161-175, 1999.

[12] Gardner, P., et al., The UK economy's requirements for people with experience of working at sea 2003, Chamber of Shipping and the Marine Society: United Kingdom. 2004.

[13] Lewarn, B. Skills shortage in the maritime industry. in Maritime Logistics Convention Sydney, 2012

[14] Cahoon, S. and H. Haugstetter. Shipping, shortages and generation Y. in 8th International Conference on Maritime Training, Communication and Technology (MARTECH). Singapore, 2008

[15] Fei, J., Knowledge management in the shipping industry: The effects of human mobility on the organisational knowledge base and effective knowledge transfer practices: A perspective from China, in Department of Maritime and Logistics Management2009, University of Tasmania: Tasmania.

[16] Gekara, V.O., Understanding attrition in UK maritime education and training. Globalisation, Societies and Education, Vol.7 No.2, 217-232, 2009.

[17] Shiptalk, Life at sea survey 2007/8: Seafarer attraction and retention, Shiptalk Publishing: Tyne and Wear. 2008.

[18] Ljung, M., Function based manning and aspects of flexibility. WMU Journal of Maritime Affairs, Vol.9 No.1, 121-133, 2010.
[19] Dyer-Smith, M., Shipboard organisation-the choices for international shipping. Journal of Navigation, Vol.45 No.3, 414-424, 1992.

[20] Fastream. Maritime salary review. 2012 25th August, 2012]; 1-16]. Available from:

http://www.faststream.com/WebFiles/ContentFiles/2012Mar itimeSalaryReview.pdf.

[21] Barnett, M., et al., Barriers to progress or windows of opportunity? A study in career path mapping in the maritime industries. WMU Journal of Maritime Affairs, Vol.5 No.2, 127-142, 2006.

[22] Deloitte. Challenge to the industry - Securing skilled crews in today's marketplace. Research on Shipping and Ports 2011 30th May, 2012]; Available from: www.deloitte.com/view/en_GX/global/industries/energy-res ources/shipping/.

[23] Oldenburg, M. and H.J. Jensen, Merchant seafaring: A changing and hazardous occupation. Occupational and Environmental Medicine, Vol.69 No.6, 132-148, 2012.

[24] Eler, G., et al., Officers' shortage: Viewpoints from stakeholders. International Journal on Marine Navigation and Safety of Sea Transportation, Vol.3 No.4, 471-474, 2009.

[25] Leggate, H., The future shortage of seafarers: Will it become a reality? Maritime Policy \& Management, Vol.31 No.1, 3-13, 2004

[26] Nigel, K., Innovation needed to meet crew shortage. Marine Log, Vol.113 No.6, 23-26, 2008.

[27] Wilden, R., S. Gudergan, and I. Lings, Employer branding: Strategic implications for staff recruitment. Journal of Marketing Management, Vol.26 No.1-2, 56-73, 2010.

[28] DNV, Corporate Social Responsibility and the shipping industry, Det Norske Veritas: Netherlands. 2004.

[29] Progoulaki, M., Dealing with the culture of the maritime manpower in a socially responsible manner, in Department of Shipping, Trade and Transport2006, University of the Aegean: Greece.

[30] Progoulaki, M. and M. Roe, Dealing with multicultural human resources in a socially responsible manner: A focus on the maritime industry. WMU Journal of Maritime Affairs, Vol.10 No.1, 7-23, 2011

[31] Cahoon, S., H. Haugstetter, and P. Bhaskar. Overcoming seafarer shortages: Human resource management and marketing strategies for a sustainable future. in International Association of Maritime Economists Conference. Lisbon, Portugal, 2010

[32] Thai, V.V. and T. Latta, Employment brand strategy for the shortage of seafarers. International Journal of Shipping and Transport Logistics, Vol.2 No.4, 411-428, 2010.

[33] Grey, M., The "image" of the shipping industry. WMU Journal of Maritime Affairs, Vol.2 No.1, 1-3, 2003.

[34] Higginbottom, K., Forget the image. The International Maritime Human Element Bulletin, Vol.5 No.9, 1 - 8, 2005 . 
[35] Magramo, M. and L. Gellada, A noble profession called seafaring: The making of an officer. International Journal on Marine Navigation and Safety of Sea Transportation, Vol.3 No.4, 475-480, 2009.

[36] Cross, S.J. Competent staff essential to ensure competent seafarers. in 18th Conference of International Maritime Lecturers' Association. Shanghai, 2010

[37] Rodriguez-Martos, R., The merchant vessel: A sociological analysis, Edicions UPC: Barcelona. 2010.

[38] Kokoszko, N., Exploring employer of choice potential in the shipping industry: An organisational perspective, in National Centre for Ports and Shipping, Austrlian Maritime College2006, University of Tasmania: Launceston. p. 1-326.

[39] Kokoszko, N. and S. Cahoon. Developing employer of choice potential in the shipping industry: An organizational perspective. in International Association of Maritime Economists Conference. Athens, 2007

[40] Gekara, V.O., Globalisation, state strategies and the shipping labour market: The UK's response to declining seafaring skills, in Seaman International Research Centre2008, Cardiff University: Cardiff.

[41] Wilkinson, S. and S. Cahoon. The shipping industry as an industry of choice extending the employer of choice strategy to overcome labour shortages. in International Association of Maritime Economists Conference. Dalian, 2008

[42] Thai, V.V., et al., Revisiting the seafarer shortage problem: The case of Singapore. Maritime Policy \& Management, Vol.40 No.1, 80-94, 2013.

[43] De Silva, R., P. Stanton, and J. Stanton, Determinants of Indian sub-continent officer-seafarer retention in the shipping industry. Maritime Policy \& Management, Vol.38 No.6, 633-644, 2011.

[44] Herman, R.E. and J.L. Gioia, Helping your organization become an employer of choice. Employment Relations Today, Vol.28 No.2, 63-78, 2001.

[45] Lillie, N., Global collective bargaining on flag of convenience shipping. British Journal of Industrial Relations, Vol.42 No.1, 47-67, 2004.

[46] Gekara, V.O. and M.I.L. Acejo. Trans-national labour and the implications for representation under globalisation; examining the case of seafaring labour and the Nautilus International cross-border merger. in ILERA (IIRA) World Congress. Philadelphia, Pennsylvania, USA, 2012

[47] Smith, C., Internationalising industrial disputes: The case of the Maritime Union of Australia. Employee Relations, Vol.32 No.6, 557-573, 2010.

[48] Zaar, S. and K. Hammarstedt, Promotion campaigns in the maritime sector and the attitude of young people towards a career at sea, in Department of Shipping and Marine Technology2012, Chalmers University of Technology: Göteborg, Sweden.

[49] Thomas, M. and N. Bailey, Square pegs in round holes? Leave periods and role displacement in UK-based seafaring families. Work, Employment \& Society, Vol.20 No.1, 129-149, 2006.
[50] Bajpaee, R. Seafarer shortages. in Connecticut Maritime Association Shipping Conference. Stamford, Connecticut, 2005

[51] Holder, L. Manning and recruiting. in BIMCO/Sohmen Forum. London, 2005

[52] Horck, J., Getting the best from multi-cultural manning. BIMCO Bulletin, Vol.100 No.4, 28-36, 2005.

[53] Watchkeeper. Tackling wastage by improving retention. in Baltic and International Maritime Council (BIMCO) Conference. Copenhagen, Denmark, 2003

[54] Wiseman, N., Consolidating international maritime labour standards. The International Maritime Human Element Bulletin, Vol.4 No.5, 1-8, 2004.

[55] Mitroussi, K. and T. Notteboom. Getting the work done: A comparative study of motivation needs and processes for seafarers and dock workers. in Asian Round Table 2012 Conference (ALRT 2012). University of British Columbia (UBC), Vancouver, 2012

[56] Fei, J., An empirical study of the role of information technology in effective knowledge transfer in the shipping industry. Maritime Policy and Management, Vol.38 No.4, 347, 2011.

[57] BIMCO/ISF, BIMCO/ISF 2000 manpower update - The world-wide demand for and supply of seafarers, Institute for Employment Research, University of Warwick. 2000.

[58] Terry, W.C., Geographic limits to global labor market flexibility: The human resources paradox of the cruise industry. Geoforum, Vol.42 No.6, 660-670, 2011.

[59] Zhao, Z., The human resource strategies of Chinese state crewing agencies with special reference to labour export and the experience of Chinese seafarers, in School of Social Sciences2011, Cardiff Univeristy: Cardiff.

[60] Yamamoto, H. Ocean transport of LNG: Toward the best framework through global collaboration. in APEC Gas Forum. Perth, Australia, 2005

[61] Moreby, D.H., The human element in shipping, Seatrade Publications: Colchester. 1975.

[62] Bowen, G.A., Document analysis as a qualitative research method. Qualitative Research Journal, Vol.9 No.2, 27-40, 2009.

[63] Owen, G., Qualitative methods in higher education policy analysis: Using interviews and document analysis, Georgia Institute of Technology: Georgia. 2013.

[64] Scott, J., A matter of record: Documentary sources in social research, Polity Press: Cambridge. 1990.

[65] Mogalakwe, M., The use of documentary research methods in social research. African Sociological Review, Vol.10 No.1, 221-230, 2006.

[66] Times Higher Education. The World University Rankings (2013-2014). 2013 7th August, 2014]; Available from: http://www.timeshighereducation.co.uk/world-university-ran kings/2013-14/world-ranking.

[67] Mason, M., Sample size and saturation in PhD studies using 
qualitative interviews. Forum: Qualitative Social Research, Vol.11 No.3, 1-19, 2010.

[68] Glass, A., Understanding generational differences for competitive success. Industrial and Commercial Training, Vol.39 No.2, 98-103, 2007.

[69] Solnet, D., A. Kralj, and J. Kandampully, Generation Y employees: An examination of work attitude differences. Journal of Applied Management and Entrepreneurship, Vol.17 No.3, 36-54, 2012. 